\title{
Rancang Bangun Sistem Deteksi Kebakaran Gedung di Universitas Islam Lamongan Berbasis Mikrokontroller Menggunakan Radio Frekuensi
}

\author{
Affan Bachri *) \\ Program Studi Teknik Elektro, Fakultas Teknik, Universitas Islam Lamongan \\ e-mail :avanbe@gmail.com
}

\begin{abstract}
ABSTRAK
Proses datangnya kebakaran selalu tanpa dapat diperkirakan dan diprediksi terlebih dahulu. Kapan datangnya, apa penyebabnya, tingkat cakupannya serta seberapa besar dampak yang ditimbulkannya, adalah hal-hal yang tidak bisa diperkirakan oleh kemampuan manusia. Perancangan sistem pengamanan kebakaran yang bertujuan untuk meningkatkan keamanan dan kenyamanan penghuni di gedung.analisa yang dilakukan adalah dengan mengukur dan mendata suhu serta melakukan serangkaian beberapa percobaan. Suhu dilengkapi dengan satuan celcius (C) dan asap menggunakan satuan PPM (part per million). Dengan cara kerja, sensor asap dan suhu akan mendeteksi secara sendiri dan bekerja dengan baik. Dan Hal ini untuk menghindari adanya kesalahan yang diakibatkan kenaikan suhu akibat sinar matahari ataupun asap akibat rokok. Jika Sensor suhu LM35 mencapai 40 C maka suhu akan mendeteksi dan buzzer akan berbunyi led akan menyalah Dan LCD 2x16 akan menampilkan "AWAS ADA ASAP". Jika Asap mencapai dari 600 ke atas sensor asap akan mendeteksi dan buzzer akan berbunyi, lampu led akan menyala lalu di LCD 2x16 akan menampilkan "AWAS ADA KEBAKARAN".
\end{abstract}

Kata kunci: Detektor Asap, Lm35, Radio Frekuensi, Mikrokontroller Atmega328.

\section{PENDAHULUAN}

Akhir-akhir ini sering terjadi kebakaran yang disebabkan oleh beberapa faktor termasuk kelalaian manusia (human error) dalam menggunakan alat-alat elektronik yang berbahaya yang bisa menimbulkan kebakaran, ataupun adanya hubungan singkat dari jaringan listrik yang ada dalam gedung atau bangunan yang akhirnya akan menimbulkan percikan api, dan beberapa faktor yang lainnya.

Proses datangnya kebakaran selalu tanpa dapat diperkirakan dan diprediksi terlebih dahulu. Kapan datangnya, apa penyebabnya, tingkat cakupannya serta seberapa besar dampak yang ditimbulkannya, adalah hal-hal yang tidak bisa diperkirakan oleh kemampuan manusia. Teknologi yang ada hanya dapat membantu memberi peringatan dini, tetapi mempunyai kemampuan yang sangat terbatas untuk memberi waktu persiapan danpertolongan dalam menghadapi bahayanya.kembangkan menggunakan modul radio frekuensi (RF) sebagai mengirim data ke alarm kebakaran, dan dapat digunakan untuk mengontrol beberapa ruangan dengan satu mikrokontroller, dapat disimpulkan pembuatan alat pendeteksi kebakaran membutuhkan biaya lebih murah.
Serta dapat memonitoring suhu ruangan dan instensitas asap dan menggunakan battrey sebagai catu daya cadangan saat terjadi pemadaman listrik.

\section{METODE PENELITIAN \\ Rancangan Penelitian}

Dalam penelitian ini metode yang digunakan meliputi perancangan rangkaian elektrik, sistematis, agar diperoleh data dan informasi yang akurat. Mulai dari pengumpulan data, perancangan, pembuatan alat, pengujian, hingga analisis hasil sistem. Gambar 3.1 menunjukkan blok diagram perancangan alat 


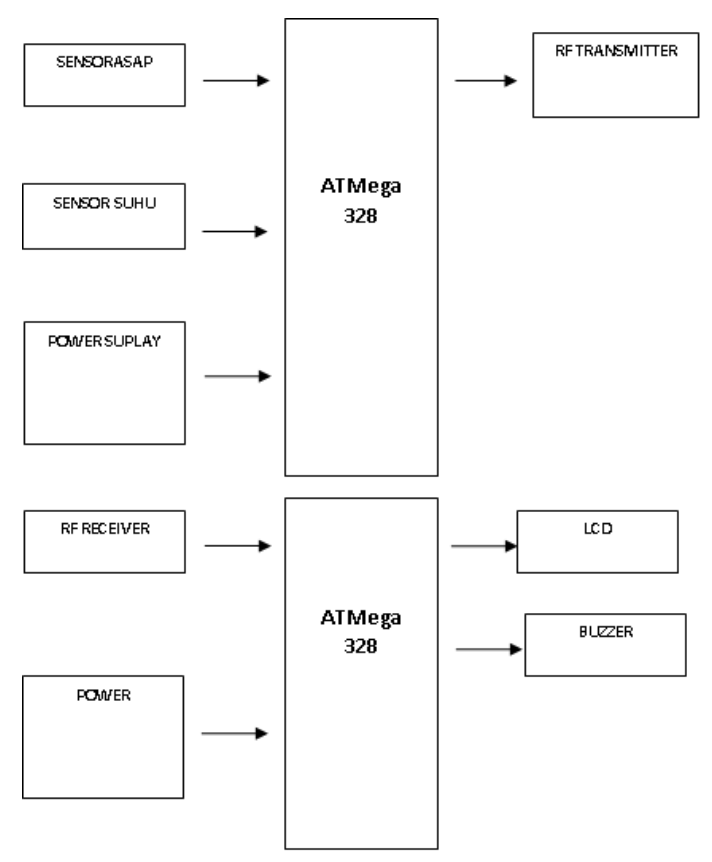

Gambar 1. Digram Blok Perencanaan Alat

\section{Perakitan perangkat keras transmitter}

Pembuatan perangkat keras transmiter yaitu dengan membuat rangkaian skema pada software Eagle, kemudian hasil gambar skemarangkaian dirangkai dengan PCB lubang, komponen disusun sesuai skema rangkaian yang telah dibuat, pada proses ini komponen Arduino, sensor ASAP,LM35, modul RF $433 \mathrm{MHz}$,power supply dan soket dipasang ke PCB. Selanjutnya, penyambungan kabel langsung ke arduino.

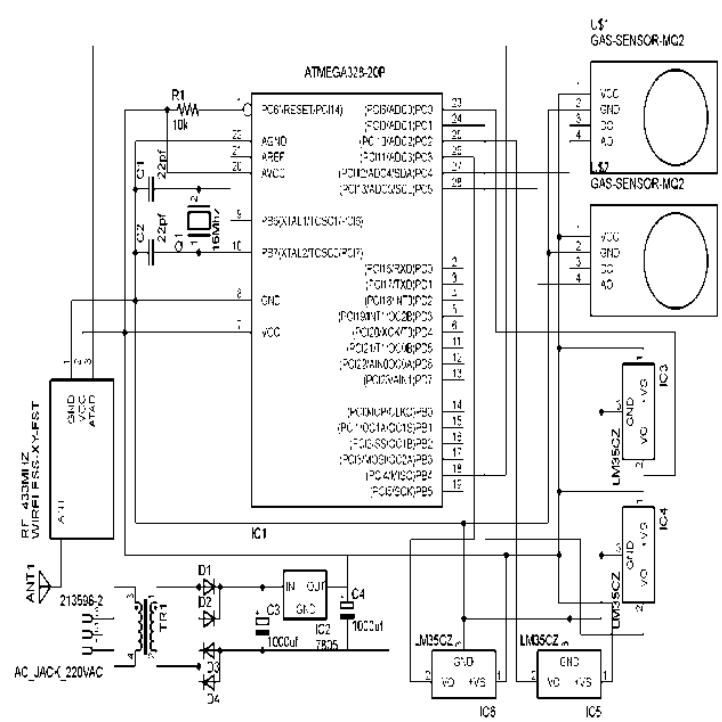

Gambar 2. Skema Perancangan Transmitter

\section{Perakitan perangkat keras receiver}

Pada perangkat keras receiver ini desain rangkaian sama menggunakan aplikasi Eagle, rangkaian receiver hanya menerima data dan menampilkan dengan LCD 16x2, komponen pada rangkaian receiver yaitu Arduino, LCD 16x2, LED indikator, buzzer, baterai dan modul receicer433 MHz.

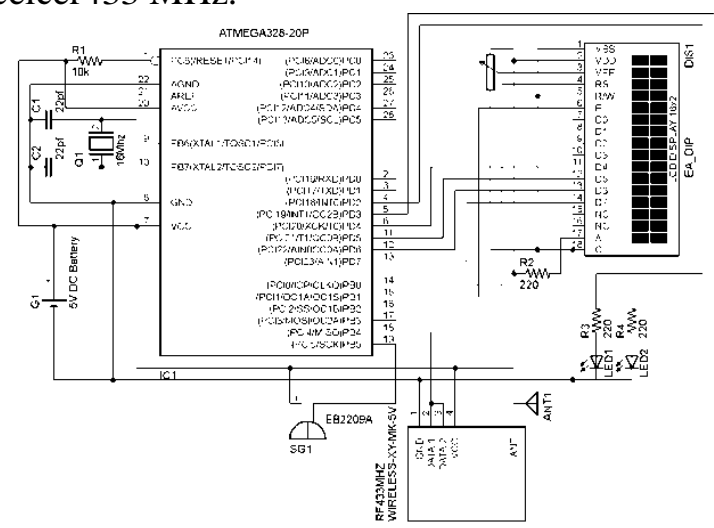

Gambar 3. Skema Perancangan Receiver

Prinsip kerja untuk mensuplai tegangannya adalah power suplay atau adaptor. Sedangkan prinsip kerja sistem, diawali dengan memasukkan data-data yang berhubungan dengan asap, suhu ruangan dan radio frequensi. Data tersebut meliputi data sensor asap,sensor suhu danradio frequensi. Data-data sensor tersebut dimasukkan kedalam mikrokontroller. Data-data yang sudah dimasukkan akan menjadi acuan mikrokontroller untuk menjalankan system. Jika kondisi sensor asap berkurang/tidak ada(dibaca oleh sensor asap) maka mikrokontroller akan menjalankan system untuk menyalakan transmiiter terus diterma oleh radio ferequensi, Jika kondisi suhu ruangan (dibaca oleh sensor suhu) maka mikrokontroller akan menjalankan system untuk menyalakan transmitter terus diterima oleh radio frequensi danHasil input data akan di tampilkan pada LCD.dan begitu seterusnya.

\section{Perancangan Rangkaian Sensor LM35}

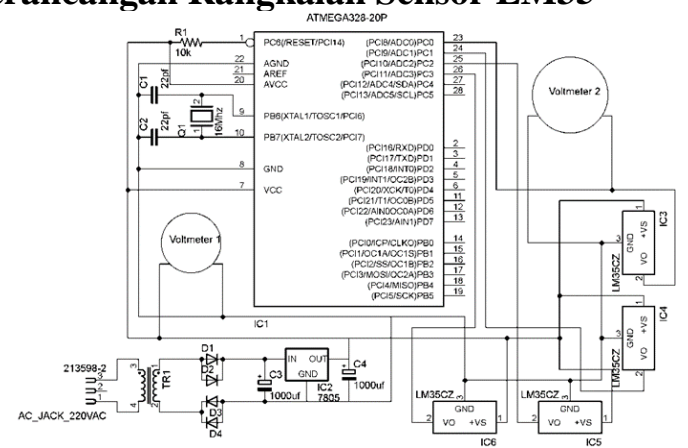

Gambar 4. Skema Pemasangan dan Pengujian Sensor $\operatorname{lm} 35$ 
Sensor LM35Berdasarkan hasil pengujian yang telah dilakukan, terukur tegangan untuk mensuplai sensor suhu LM35 sebesar 4,9 Volt, dan didapatkan tegangan output pada sensor suhu LM35 yang berubah-ubah nilainya sesuai suhu ruangan yang diukur, sesuai tabel diatas didapatkan tegangan $0,3-0,38$ Volt pada suhu antara 30 - 45 derajat celcius. Dan didapatkan perbedaan suhu pada pembacaan sensor suhu di tampilan LCD $2 \times 16$ dan termometer ruangan. Namun perbedaan tersebut hanya mempunyai selisih yang cukup sedikit. oleh karena itu disimpulkan bahwa termometer dapat berfungsi dengan baik dan sesuai kegunaannya.

\section{Perancangan Rangkaian Sensor Asap}

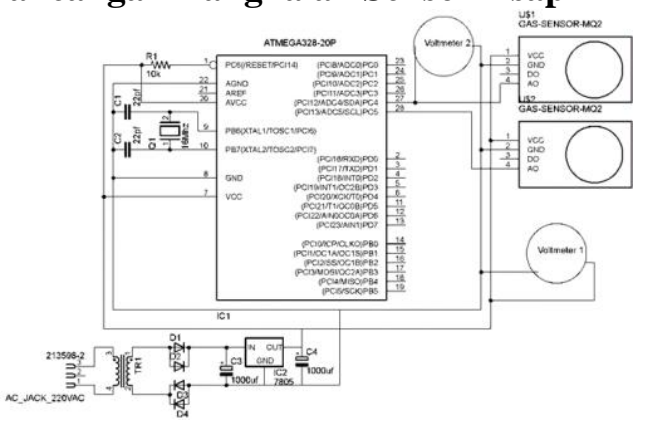

Gambar 5. Skema Pemasangan dan Pengujian Sensor Asap

Hasil dari pengukuran intensitas asap pada sensor asap terukur tegangan input ke sensor asap sebesar 4,6 Volt DC yang disupply dari Arduino, kemudian didapatkan hasil pengukuran sensor berupa tegangan analog yang nilainya berubah naik ketika terdeteksi asapdan sebaliknya, dapat dilihat di tabel 4.2. didapatkan pengukuran tegangan output pada voltmeter 2 antara 0,11 0,51 Volt DC. Dan hasil pengukuran Analog pada SerialMonitor Arduino IDE antara 29 sampai 113.Dan didapatkan hasil konversi dari nilai Analog ke Satuan PPM anatara 279 - 629 PPM.Sensor asap akan mendeteksi sendiri jika asap mencapai 629 dan Sensor asap akan bekerja dengan baik.

\section{Perancangan Rangkaian Modul RF}

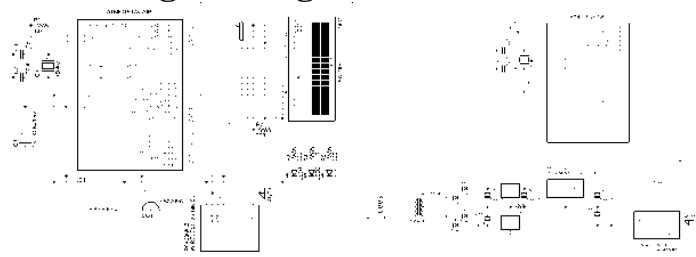

Gambar 6. Skema Pemasangan dan Pengujian Modul Radio Frekuensi
Modul RF 433 Mhz ini digunakan untuk mengirim informasi data kebakaran tiap ada kebakaran dan notifikasi terjadinya gangguan dari mikrokontroler pengirim ke mikrokontroler penerima. Pada pembuatan Remot Notifikasi Gangguan ini menggunakan Modul Radio Frekuensi dengan frekuensi $433 \mathrm{mHz}$. Mitode pengujian modul RF 433Mhz dilakukan dengan memberi variasi jarak antara modul Pengirim RF dan modul penerima RF.

\section{HASIL PEMBAHASAN \\ Hasil Pengujian Rangkaian}

Pengujian rangkaian dilakukan dengan pengujian sensor kebakaran ruangan, kemudian dilanjutkan dengan pengujian untuk mengetahui jarak maksimum transmisi data dengan modul RF $433 \mathrm{MHz}$ baik tanpa halangan maupun dengan halangan. Untuk mensimulasikan variasi kebakaran dan tampilan LCD 16x2 dilakukan dengan cara memberikan macam macamkebakran pada sensor. Untuk mengetahui jarak maksimum transmisi data digunakan catu daya 5 Volt dan baudrate 500bps pada modul RF $433 \mathrm{MHz}$.

\section{Hasil Pengujian Rangkaian LM35}

Pada tahap ini Sensor kebakaran ini menggunakan sensor suhu (LM35) sehingga dilakukan pengujian pada hasil pembacaan kebakaran yang sudah dikoversi oleh sistem program Arduino.Berdasarkan hasil pengujian yang telah dilakukan, terukur tegangan untuk mensuplai sensor suhu LM35 sebesar 4,9 Volt, dan didapatkan tegangan output pada sensor suhu LM35 yang berubah-ubah nilainya sesuai suhu ruangan yang diukur, sesuai tabel diatas didapatkan tegangan $0,3-0,38$ Volt pada suhu antara 30 - 45 derajat celcius. Dan didapatkan perbedaan suhu pada pembacaan sensor suhu di tampilan LCD $2 \times 16$ dan termometer ruangan. Namun perbedaan tersebut hanya mempunyai selisih yang cukup sedikit. oleh karena itu disimpulkan bahwa termometer dapat berfungsi dengan baik dan sesuai kegunaannya 
Tabel 1. Data Hasil Pengujian Rangkaian Suhu LM35

\begin{tabular}{|cc|c|c|}
\hline $\begin{array}{c}\text { Hasil pengukuran } \\
\text { Volmeter 1 (Volt) }\end{array}$ & $\begin{array}{c}\text { Hasil pengukuran } \\
\text { Volmeter 2 (volt) }\end{array}$ & $\begin{array}{c}\text { Hasil Pengukuran } \\
\text { Thermometer }\end{array}$ & $\begin{array}{c}\text { Hasil Pengukuran } \\
\text { Sensor Suhu LM35 }\end{array}$ \\
\hline 4,9 & 0,34 & 30 & 35 \\
\hline 4,9 & 0,31 & 31 & 31 \\
\hline 4,9 & 0,3 & 32 & 30 \\
\hline 4,9 & 0,32 & 30 & 33 \\
\hline 4,9 & 0,38 & 40 & 41 \\
\hline 4,9 & 0,38 & 43 & 41 \\
\hline 4,9 & 0,37 & 45 & 40 \\
\hline
\end{tabular}

\section{Hasil Pengujian Rangkaian LM35}

Sensor kebakaran ini menggunakan sensor Asap (MQ) sehingga dilakukan pengujian pada hasil pembacaan kebakaran yang sudah di koversi oleh sistem program Arduino. Pada tabel di bawah ini merupakan hasil pengujian sensor Asap MQ dan Analog. Hasil dari pengukuran intensitas asap pada sensor asap terukur tegangan input ke sensor asap sebesar 4,6 Volt DC yang disupply dari Arduino, kemudian didapatkan hasil pengukuran sensor berupa tegangan analog yang nilainya berubah naik ketika terdeteksi asapdan sebaliknya, dapat dilihat di tabel 4.2. didapatkan pengukuran tegangan output pada voltmeter 2 antara $0,11-0,51$ Volt DC. Dan hasil pengukuran Analog pada SerialMonitor Arduino IDE antara 29 sampai 113.Dan didapatkan hasil konversi dari nilai Analog ke Satuan PPM anatara 279 - 629 PPM.Sensor asap akan mendeteksi sendiri jika asap mencapai 629 dan Sensor asap akan bekerja dengan baik

Tabel 2. Data Hasil Pengujian Rangkaian Sensor asap

\begin{tabular}{|c|c|c|c|}
\hline $\begin{array}{c}\text { Hasil Pengukuran } \\
\text { Voltmeter 1 (Volt) }\end{array}$ & $\begin{array}{c}\text { Hasil Pengukuran } \\
\text { Voltmeter 2 (Volt) }\end{array}$ & $\begin{array}{c}\text { Hasil Pengukuran } \\
\text { Analog di Serial } \\
\text { Monitor }\end{array}$ & $\begin{array}{c}\text { Hasil Pengukuran } \\
\text { Sensor Asap } \\
\text { MQ(ppm) }\end{array}$ \\
\hline 4,6 & 0,51 & 113 & 629 \\
\hline 4,6 & 0,4 & 102 & 629 \\
\hline 4,6 & 0,11 & 29 & 279 \\
\hline 4,6 & 0,28 & 71 & 485 \\
\hline 4,6 & 0,12 & 30 & 288 \\
\hline 4,6 & 0,25 & 60 & 422 \\
\hline
\end{tabular}

\section{Pengujian Rangkaian RF 433 Mhz}

\section{a. Pengujian Transmisi Data Luar Ruangan}

Pengujian pertama dilakukan pada tempat terbuka yang memiliki luas kurang lebih 20 meter dan tidak memiliki halangan apapun. Kemudian, pengujian dilakukan dengan memasang rangkaian transmitter dan rangkaian receiver dengan range jarak yang berbeda, mulai dari jarak yang terdekat sampai jarak yang paling jauh. Maka didapatkan hasil pengujian yang peneliti cantumkan dalam bentuk tabel sebagai berikut.

Tabel 3. Tabel Hasil Pengujian Modul RF di Luar Ruangan

\begin{tabular}{|c|c|c|c|c|}
\hline Catu Daya & $\begin{array}{c}\text { Jarak } \\
\text { Transmisi }\end{array}$ & $\begin{array}{c}\text { Status } \\
\text { Pengiriman }\end{array}$ & $\begin{array}{c}\text { Hasil Data } \\
\text { Dikirim }\end{array}$ & $\begin{array}{c}\text { Hasil Data } \\
\text { Diterima }\end{array}$ \\
\hline \multirow{9}{*}{5 Volt } & 2 meter & Sukses & 6 Data & 6 Data \\
\hline & 4 meter & Sukses & 6 Data & 6 Data \\
\hline & 6 meter & Sukses & 6 Data & 6 Data \\
\hline & 8 meter & Sukses & 6 Data & 6 Data \\
\hline & 10 meter & Sukses & 6 Data & 6 Data \\
\hline & 12 meter & Sukses & 6 Data & 6 Data \\
\hline & 14 meter & Sukses & 6 Data & 6 Data \\
\hline & 16 meter & Sukses & 6 Data & 6 Data \\
\hline & 18 meter & Gagal & 6 Data & 3-4 Data \\
\hline
\end{tabular}

\section{b. Pengujian Transmisi Data Dalam Ruangan}

Pengujian transmisi data dengan kondisi melalui halangan ini dilakukan didalam bangunan satu lantai yang luasnya beragam dengan ketebalan tembok $\pm 14 \mathrm{~cm}$ dengan material bata, pasir, dan semen dan pada ruangan tersebut terdapat perangkat elektronik lainya. Denah bangunan yang digunakan untuk pengujian alat adalah sebagai berikut:

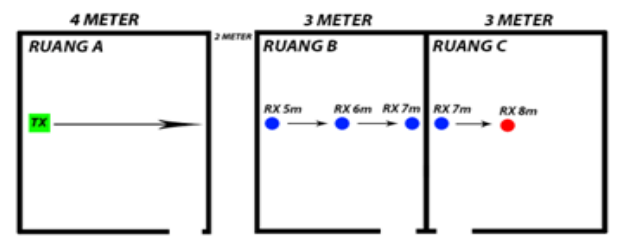

Gambar 7. Denah Pengujian Dalam Ruangan

Bagian transmitter ditempatkan di salah satu ruangan, sedangkan bagian receiver berpindahpindah untuk memberikan variasi jarak. Sebagai penjelasan dari peletakan Transmitter dan Receiver dalam penjelasan berupa posisi sebagai berikut.

Transmitter (dilambangkan dengan simbol kotak hijau bertanda Tx) berada di ruang A memancar dengan catu daya 5 Volt, sedangkan receiver (dilambangkan dengan simbol bulat biru bertanda $\mathrm{Rx}$ ) berada di ruang $\mathrm{B}$ menerima data dengan catu daya 5 Volt. Transmitter tetap pada posisinya, sedangkan receiver bergeser menjauh segaris dengan transmitter (ditandai dengan garis panah) untuk memberikan variasi jarak. Posisi bulat merah pada gambar menandakan posisi akhir kegagalan data diterima akibat jarak dan jumlah tembok melebihi jumlah yang dapat ditembus oleh sinyal.

Dari pengujian diatas didapatkan bahwa transmisi data optimal dalam ruangan yaitu pada catu daya 5 Volt, baudrate 500 bps dan jarak terjauhnya adalah 7 meter dengan melalui 
halangan 2 tembok. Ketebalan tembok sangat berpengaruh pada sampainya sinyal transmisi data dari transmitter kereceiver. Semakin banyak, semakin rapat, semakin tebal material halangan tersebut dan semakin banyak perangkat elektronik pada ruangan, maka sinyal transmisi makin sulit untuk diterima oleh receiver.

Karena, gelombang radio ditransmisikan melalui media udara. Maka adanya banyak gangguan radiasi gelombang radio lain dari perangkat elektronik dan sedikit celah akan mampu menghalang transmisi data kepada receiver.

Tabel 4. Tabel Hasil Pengujian Transmisi Data dalam Ruangan

\begin{tabular}{|c|c|c|c|c|c|}
\hline Catu Daya & Jarak (M) & $\begin{array}{c}\text { Halangan } \\
\text { Tembok }\end{array}$ & $\begin{array}{c}\text { Hasil } \\
\text { Terkirim }\end{array}$ & $\begin{array}{c}\text { Hasil } \\
\text { Diterima }\end{array}$ & Status \\
\hline \multirow{5}{*}{5 Volt } & $5 \mathrm{~m}$ & 1 & 6 Data & 6 Data & Sukses \\
\hline & $6 \mathrm{~m}$ & 1 & 6 Data & 6 Data & Sukses \\
\hline & $7 \mathrm{~m}$ & 1 & 6 Data & 6 Data & Sukses \\
\hline & $7 \mathrm{~m}$ & 2 & 6 Data & 6 Data & Sukses \\
\hline & $8 \mathrm{~m}$ & 2 & 6 Data & 3 Data & Gagal \\
\hline
\end{tabular}

\section{Pengujian Rangkaia Keseluruhan}

Pengujian sistem keseluruhan menggunakan baterai pada bagian receiver, rangkaian transmitter yaitu 6 sensor yang dipasang dalam 2 ruangan. Untuk mendapatkan nilai kebakaran, sensor kebakaranpertama dipasang pada Ruangan A dan sensor kedua di Pasang pada Ruangan B. Untuk Jalursemua sensor ditempatkan ke arduino atauRangkaian kedua yaitu rangkaian receiver yang terdiri dari Arduino Uno R3 dan LCD 16x2, LED indikator dan Buzzer yang berfungsi untuk menampilkan hasil pengukuran suhu dan asap pada rangkaian transmitter.

Tabel 5. Tabel Hasil Pengujian Rangkaian keseluruhan

\begin{tabular}{|ccc|cccccccc}
\hline \multicolumn{3}{|c|}{ Ruang A } & \multicolumn{3}{c}{ Ruang B } & \multicolumn{5}{c}{ Hasil Pengujian } \\
\hline $\begin{array}{c}\text { Sensor } \\
\text { suhu 1 }\end{array}$ & $\begin{array}{c}\text { Sensor } \\
\text { suhu 2 }\end{array}$ & $\begin{array}{c}\text { Sensor } \\
\text { asap }\end{array}$ & $\begin{array}{c}\text { Sensor } \\
\text { suhu 1 } 1\end{array}$ & $\begin{array}{c}\text { Sensor } \\
\text { suhu 2 }\end{array}$ & $\begin{array}{c}\text { Sensor } \\
\text { asap }\end{array}$ & pendeteksi & Jarak RF RX & RX & $\begin{array}{c}\text { Pemberit } \\
\text { ahuan }\end{array}$ \\
\hline 41 & 35 & 225 & 33 & 32 & 222 & Aktif(RA) & 10 meter & Sukses & Sukses \\
\hline 33 & 42 & 330 & 34 & 33 & 250 & Aktif(RA) & 10 meter & Sukses & Sukses \\
\hline 35 & 33 & 665 & 32 & 34 & 290 & Aktif(RA) & 10 meter & Sukses & Sukses \\
\hline 32 & 33 & 300 & 41 & 32 & 280 & Aktif(RB) & 10 meter & Sukses & Sukses \\
\hline 33 & 34 & 285 & 33 & 40 & 271 & Aktif(RB) & 10 meter & Sukses & Sukses \\
\hline 34 & 33 & 266 & 32 & 33 & 660 & Aktif(RB) & 10 meter & Sukses & Sukses \\
\hline 32 & 33 & 223 & 33 & 34 & 220 & Tidak aktif & 10 meter & Sukses & Sukses \\
\hline 33 & 34 & 225 & 34 & 35 & 230 & Tidak aktif & 10 meter & Sukses & Sukses \\
\hline
\end{tabular}

\section{PEMBAHASAN}

Dari pengujian yang telah dilakukan dari pengujian sensor pendeteksi kebakaran dan sampai pengujian keseluruhan pada setiap bagian dapat bekerja dengan baik. Keenam sensor dapat bekerja dengan baik. Serta transmitter RF 433 Mhz dapat mampu mengirim data dan menerima data. Pada tabel 4.1.pengujiandilakukan pada berapa sumber Ssuhu, pada rangkaian transmitter sensor suhu dapat membaca suhu. Selanjutnya data sensor dikirim oleh rangkaian RF $433 \mathrm{MHz}$. kemudian data diterima rangkaian receiver 433 $\mathrm{MHz}$ dan ditampilkan di LCD 16x2 dan LED indikatorsesuai sensor yang dikirim.

Pada percobaan kedua, pengujian dilakukan dengan menggunakan sensor asap, pada rangkaian transmitter sensor asap dapat membaca intensitas kepekatan asapselanjutnya data sensor dikirim oleh rangkaian RF $433 \mathrm{MHz}$. kemudian data diterima rangkaian receiver $433 \mathrm{MHz}$ dan ditampilkan di LCD 16x2 dan LED indikatorsesuai sensor yang dikirim.

Dalam pengujian kali ini masih terdapat beberapa hasil yang kurang, yaitu pada setiap pembacaan sensor masih kurang sesuai dan kurang sensitif serta membutuhkan waktu untuk mengidentifikasi pada parameternya. Dan pada pengiriman data jarak maksimal yang dapat dijangkau 20 meter sampai 30 meter dan pada ruang terbuka. Jika pada terdapat halangan seperti ruang/ tembok pengiriman sulit untuk mengirim data. Makin sulit untuk diterima oleh receiver. Karena, gelombang radio ditransmisikan melalui media udara. Maka adanya banyak gangguan radiasi gelombang radio lain dari perangkat elektronik dan sedikit celah akan mampu menghalang transmisi data kepada receiver.

\section{PENUTUP \\ Kesimpulan}

Berdasarkan hasil pengujian dan analisa rangkaian alat rancang bangun sistem deteksi kebakaran gedung di universitas islam lamongan berbasis mikrokontroller menggunakan radio frekuensi:

1. Sistem pendeteksi kebakaran yang dibuat bekerja sesuai dengan yang diharapkan, yaitu ketika terdapat suhu dan asap. Maka sensor asap dan suhu akan mendeteksi secara sendiri dan bekerja dengan baik. Dan Hal ini untuk menghindari adanya kesalahan yang diakibatkan kenaikan suhu akibat sinar matahari ataupun asap akibat rokok. Jika Sensor suhu LM35 mencapai 40 C maka suhu akan mendeteksi dan buzzer akan berbunyi led akan menyalah Dan LCD 2x16 akan menampilkan "AWAS ADA ASAP". Jika Asap mencapai dari 600 ke atas sensor asap akan mendeteksi dan buzzer akan berbunyi, lampu led akan menyala lalu di LCD 2x16 
akan menampilkan "AWAS ADA KEBAKARAN".

2. Pembuatan perangkat lunak atau kode pemograman Arduino untuk menampilkan suhu asap dan suhu ruangan, dimulai dengan menambahkan library modul yang digunakan, pada penelitian ini digunakan library Radio Frekuensi, kemudian dilanjutkan dengan pengenalan pin kaki sensor pada mikrokontroler Arduino. Kemudian Arduino mengolah data yang didapatkan dari semua sensor untuk dideteksi apakah nilai tersebut melebihi batas yang sudah ditentukan. Jika tidak mendeteksi adanya nilai yang melebihi batas, Arduino akan mengirim nilai-nilai sensor ke perangkat penerima melalui modul Radio Frekuensi, dan ditampilkan value nilai yang didapatkan oleh sensor

\section{PUSTAKA}

Ahmad Faishal, Maun Budiyanto, Pendeteksi Kebakaran Dengan Menggunakan Sensor Suhu LM35D dan sensor asap", Jurnal Program Diploma Teknik Elektro Vokasi UGM, yogyakarta jalan yacaranda sekip unit IV yogyakarta, 2010.

Agus Nuryadi, Prototipe Penyiram Tanaman Otomatis Tanaman Cabai Berbasis Mikrokontroller ATMega 16 Yogyakarta, 2015.

Budiharto, Widodo, dan Gamayel Rizal, Belajar Sendiri 12 Proyek Mikrokontroler untuk Pemula, Elex Media Komputindo, Jakarta, 2007.

Devin Favian, Heri Supomo, Perancangan sistem deteksi kebakaran berbasis komputer untuk galangan kapal", jurnal jurusan teknik perkapalan, fakultas teknologi kelautan, institut teknologi sepuluh nopember (ITS), 2012.

Datasheet

ATMega328. 2015.

(http://www.atmel.com/images/Atmel-

8271-8-bit-AVR-Microcontroller-

ATmega48A-48PA-88A-88PA-168A-

168PA-328-

328P_datasheet_Complete.pdf).

(download). diakses tanggal 24 Maret 2017.

Fardhan Arkan, Sistem detektor kebakaran untuk rumah susun dengan sistem wireless sensor network", jurusan teknik elektro fakultas teknik universitas bangka belitung, 2014.
Tole Sutikno, Wahyu Sapto Aji, Rahmat Susilo. Perencanaan Alat Pendeteksi Kebakaran Berdasarkan Suhu dan Asap Berbasis Mikrokontroller AT89S52”, Jurnal, Teknik Elektro, Fakultas Teknlogi Industri, Universitas Ahmad Dahlan, Yogyakarta, 2006.

Wahyu Santoso, Eko. Prototype Penyiraman Tanaman Otomatis Dengan Sensor Kelembaban Tanah Berbasis Mikrokontroller ATMega328", Skripsi S1, Teknik Elektro, Fakultas Teknik, Universitas Islam Lamogan, Lamongan, 2016. 
JE-Unisla , Vol 4 No 1 Maret 2019 | 234 